\title{
Discursive Technologies of Self-Designing Personality
}

\section{Дискурсивные технологии самопроектирующейся личности}

\author{
Natalia Chepeleva \\ The full member of the NAPS \\ of Ukraine, Dr. in Psychology, \\ Professor, Deputy Director \\ of Research Work
}

\author{
Наталия Чепелева \\ действительный член \\ НАПН Украины, доктор \\ психологических наук, профессор, \\ заместитель директора по научно- \\ исследовательской работе
}

E-mail: chepelevan@gmail.com orcid.org/0000-0002-2085-4148

\section{Svitlana Rudnytska}

Dr. in Psychology, Associate

Professor, Head of Laboratory

of Cognitive Psychology

\section{Светлана Рудницкая}

доктор психологических наук, доцент, заведующая лаборатории когнитивной психологии

E-mail: rudnsvit@gmail.com orcid.org/0000-0002-0141-6337

G.S. Kostiyk Institute of Psychology of the National Academy of the NAPS of Ukraine 2, Pankivska Str., Kyiv, Ukraine, 01033
Институт психологии имени Г.С. Костюка НАПН Украинь

$\bowtie$ ул. Паньковская, 2, г. Киев, Украина, 01033

Original manuscript received September 14, 2018

Revised manuscript accepted March 15, 2019 


\section{ABSTRACT}

The article presents and analyzes a three-level model of a self-designing personality ("plagiarist», "reader», "author») and describes the psychological characteristics of the subject of self-designing on each of them. In the optics of the psycho-hermeneutic approach, the conception of discursive technology as a communicative-and-semiotic process is proposed. The process provides storage, accumulation, transformation, translation and retranslation of the value-semantic resource incorporated into certain sign-symbolic forms, in particular, in a wide range of sociocultural and personal texts. It is shown that discursive technologies at each of the selected self-designing levels have an expressed specificity, due to the methods of the individual experience organizing, the text objectification of this experience, sense-formation strategies and understanding procedures. The basic discursive technology at the level of "plagiarist» is the statement. The technology of transition to the "reader» level is an informational dialogue, in the process of which the topic of statements is explicated, which, in turn, starts the process of structuring, framing the individual "vital material» and creating narrative constructs. The narrative becomes the main discursive technology of the personality at the "reader" level. To go to the optional "author» level a personality has to master the technology of semantic dialogue, during which the creation of auto-narratives takes place. At the "author» level, thanks to a certain value-semantic "logic» of the auto-narratives integration into a single semantic whole, a personality vital product is born. The leitmotif appears the backbone of the product, as well as the means of navigation of the personality within it. It is generalized that the discursive technologies of personality self-designing are directed to the thematic organization of life situations at the "plagiarist" level; the space-and-time and cause-and-effect structuring of life events at the "reader» level; value- and-semantic integration of the life history at the "author» level.

Key words: text, self-designing, narrative, discursive technologies of self-designing, informational dialogue, semantic dialogue.

\section{Вступление}

Экспансия идей лингвистического поворота, привнесшего качественные трансформации в гуманитарное знание XX века, привела к принципиальному переосмыслению таких концептов, как «язык», «дискурс», «текст», «нарратив», а также существенному расширению сферы их применения. В оптике психологогерменевтичного подхода, составляющего методологическую основу нашего исследования, именно эти концепты рассматриваются как универсальные маркеры, выразители и трансляторы готовности личности к самопроектированию, становлению позиции авторства 
собственной жизни (Bauer \& McAdams, 2004; Baddeley \& Singer, 2007; Habermas \& de Silveira, 2008; Hammack, 2008; McAdams, 2008; McLean, Pasupathi \& Pals, 2007; Pals, 2006; Sarbin, 1986).

В контексте вышесказанного целесообразно говорить о дискурсивном самопроектировании, поскольку человек самоопределяется, самоконструируется в дискурсе. Именно дискурс является не просто инструментом присвоения культуры, но важнейшим инструментом личностной самодетерминацией человека в культуре, расширения границ самого себя, построения собственного смыслового пространства. Кроме того, тексты культуры являются основным источником культурно приемлемых личностных и жизненных проектов, на основании которых строятся персональные тексты, отражающие эти, а также возможные пути самоинтерпретации, самопостижения, самоконструирования. Тем самым создается смысловое пространство личности, в котором рождаются новые смыслы, разрабатываются идеальные проекты и жизненные стратегии, формируются новые самоидентификации и т. д.

Таким образом, осмысление социокультурного и индивидуального опыта, а также его воплощение в дискурсивной форме может выступать основой для выстраивания личностного проекта, осуществляемого в процессе дискурсивных практик и выработке на их основе технологий самопроектирования, что, в свою очередь, является основой для становления зрелой личности, способной решать разнообразные жизненные задачи.

В этой связи огромное значение приобретают исследования дискурсивных технологий (Казаков, 2011; Тюнников, 2000), в частности, дискурсивных технологий самопроектирующейся личности (Самопроектування особистості у дискурсивному просторі, 2016), которые на сегодняшний день являються малочисленными, а их результаты свидетельствуют о недостаточном изучении проблемы.

Цель исследования - выделить и охарактеризовать основные дискурсивные технологии самопректирующейся личности.

Задача исследования - согласно авторской модели самопроектирующейся личности: «плагиатор» - «читатель» «автор», выделить дискурсивные технологии, применяемые на каждом из этих уровней, а также технологии межуровневого 
перехода и проанализировать их специфику в контексте создания личностного и жизненного проектов.

\section{Методы и методики исследования}

Конструирование дискурсивных технологий самопректирующейся личности основывается на междисциплинарных возможностях психологической науки. В качестве мировоззренческой и методологической базы исследования применяется аппарат феноменологии и герменевтики как парадигм диалогокультурологического и семиотически-семантического направления, которые ориентируются на процесс понимания (интерпретации) личных и социокультурных смыслов.

Теоретическим базисом конструирования технологий самопроектирующейся личности выступает философскокультурологическая концепция У. Эко, позволяющая выявить специфику процессуальной природы знака в коммуникациях (Eco, 1984), что, с нашей точки зрения, является основанием для коммуникативно-семиотического моделирования различных психологических и социокультурных феноменов.

В данном исследовании для построения и анализа модели самопроектирующейся личности, конструирования дискурсивных технологий самопроектирования мы используем метод коммуникативно-семиотического моделирования, предполагающий изучение вышеобозначенных феноменов с помощью выделения их базисных составляющих, позволяющий сформировать представления о коммуникативно-семиотических механизмах порождения и трансляции дискурсивных технологий самопроектирования на различных уровнях этого процесса («плагиатор», «читатель», «автор») (Чепелєва \& Рудницька, 2018), в частности, о нарративизации - ведущем механизме конструирования как дискурсивных, так и гуманитарных технологий в целом (Проблемы психологической герменевтики, 2009).

Основным преимуществом используемого нами метода является возможность рассматривать дискурсивные технологии самопроектирования личности как динамическую конфигурацию: высказывание - автонарратив - произведение, имплицируемую и транслируемую в процессе информационного и смыслового диалога. 


\section{Результаты и дискуссии}

Дискурсивные технологии трактуются нами как технологии создания, упаковки, расшифровки и функционирования смыслов. Они направлены на обеспечение возможности личности управлять собственными ресурсами, осознавать, интерпретировать, переживать и трансформировать саму себя и собственную жизнь, что и обусловливает целесообразность и перспективность использования их в процессе самопроектирования. В частности, использование таких технологий открывает возможности выстраивания смысложизненных ориентаций, самостоятельной постановки задач личностного развития, формирования жизненных стратегий и их воплощении в разнообразных жизненных и повседневных практиках.

Опираясь на идеи К. Гергена, можно выделить следующие характеристики дискурсивных технологий: гибкость точки зрения; осознание конструирования; ориентация на диалог, коммуникацию, сотрудничество; ориентация на дискурс; ориентация на многоголосие (т.е. многообразие «Я»); ориентация на перспективу; ориентация на действие. При этом формой действия является сам дискурс - он не описывает действие, а является именно его формой (Gergen, 1999; Wittgenstein, 2009).

Прежде, чем давать характеристику дискурсивных технологий самопроектирования, остановимся на основных параметрах личности, склонной к созданию собственного жизненного, а главное - личностного проектов.

Личность, склонная к самопроектированию должна обладать целым рядом характеристик, дающих ей возможность создавать жизненный и личностные проекты, осознавать и анализировать их, а также воплощать, опираясь на ожидаемые результаты и трансформируя их в зависимости от воплощения ожиданий.

Прежде всего, можно говорить о склонности к самопроектированию, если у человека есть направленность на саморазвитие, изменение своих жизненных обстоятельств и личностных характеристик. При этом, опираясь на Д.А. Леонтьева, мы говорим о трех измерениях развития - биологическом, социальном и собственно личностном (Леонтьев, 2013), выделяя на каждом из них следующие параметры: способ организации 
опыта личности, текстовая объективации этого опыта, стратегии смыслообразования, способы и процедуры понимания.

В случае биологического измерения смыслы, которые характерны для такой личности, можно назвать заданными. Опираясь на эти смыслы, человек руководствуется такой стратегией смыслообразования, как стереотипизирование. Это наиболее примитивная стратегия, используя которую личность копирует имеющиеся в культуре и социумы образцы, не задумываясь ни о смысле собственной жизни, ни о путях своего дальнейшего развития, направленного на воплощение этих смыслов. Зачем, если они уже есть и вполне его устраивают. Такую личность условно можно назвать «копировальщиком» или «плагиатором».

В рамках данного измерения развития наиболее типичным является понимание на значенческом уровне, т.е. человек не пытается проникнуть в глубинную (смысловую) структуру воспринимаемых текстов (как письменных, так и сообщений, транслируемых окружающими), оставаясь на уровне внешней, поверхностной структуры воспринимаемого сообщения. Тексты, которые строятся в результате такого понимания, являются трафаретными, копирующими внешнюю структуру воспринимаемого сообщения. Условно мы назвали их высказываниями.

Однако личность уже начинает создавать нарративы, которые копируют известные ей фабулу и сюжет, меняя только героев своих нарративов, характеристики которых воспроизводят характеристики героев воспринятых произведений.

Если же личность находится в рамках второго (социального) измерения собственного развития, то смыслы, которыми она пользуется, можно назвать присвоенными, а стратегию смыслопорождения - смыслопоглощающей. В данном случае личность не просто копирует имеющиеся в культуре и социуме смысловые образцы, а поглощает, присваивает их, однако, еще не пытается на этой основе создать свои собственные смысловые системы. На этом уровне развития происходит переход от условно плагиатора к личности, которую можно назвать читателем, однако, читателем, который еще не задействует высшие, диалогические приемы понимания социокультурных текстов и почти не создает своих, а в основном присваивает тексты, имеющиеся в культуре и социуме. 
В рамках данного измерения личность начинает использовать интерпретативные процессы, хотя большинство интерпретационных рамок еще заимствуются извне. Человек начитает воспринимать сюжет социокультурных текстов и, используя интерпретацию, создает собственные сюжеты с созданными им героями и персонажами. Основным способом текстообразования на этом уровне является нарратив, однако его ткань насыщена чужими цитатами.

И, наконец, третий - личностный уровень развития, который, по Д.А. Леонтьеву (Леонтьев, 2013), является факультативным, личность переходит к созданию собственных смысловых систем, что, в свою очередь, является основой для создания собственных жизненных и личностных проектов. Такого человека можно назвать автором - автором собственной жизни и собственной личности.

Здесь начинает задействоваться диалогическое понимание, базирующееся на собственной интерпретации и столкновении, сопоставлении социокультурных и личностных смыслов. Понимание является как смысловым, так и метасмысловым. Личность начинает создавать собственные нарративы, ориентируясь не только на социокультурные сюжеты, но и на метасюжеты и создавая на их основе свои, применяя максимально широкую палитру способов текстообразования. Основным способом текстообразования на этом уровне является нарративизация, ведущая к порождению автонарратива, который, в свою очередь, трансформируется в произведение, под которым мы понимаем смысловую форму персонализированного воплощения человека, т.е. пространство рождения автора. По М. Мамардашвили произведение есть текст, внутри которого создается человек, способный написать этот текст. Вот в том разрезе, где мы движемся, именно там произведения производят авторов произведений. То есть из таинственных глубин человеческого «Я» они извлекают то, о чем человек в себе не подозревал и чем не мог бы стать без произведения (Мамардашвили, 2001).

Именно автор способен создавать проективные тексты, т.е. тексты, в которых заложен проект желаемого «Я». Это связано с такими характеристиками автора, как проективность, ответственность, контекстуальность, событийность, способность к порождению смысла, уникальность. Это именно те характеристики, 
которые дают возможность человеку проецировать себя как личность во все, чем он занимается, и в то, как живет (Воробьева, 2004).

Таким образом, основные дискурсивные технологии на каждом из выделенных нами уровней самопроектирующейся личности: «плагиатора», «читателя», «автора» (соотносимых с измерениями развития личности по Д.А. Леонтьеву (Леонтьев, 2013), имеют свою выраженную специфику, обусловленную способами организации опыта личности, текстовой объективации этого опыта, стратегиями смыслообразования, способами и процедурами понимания (Чепелєва \& Рудницька, 2018).

Важно отметить, что выделение этих уровней, очевидно, носит условный характер и является перспективным исследовательским приемом, позволяющим моделировать дискурсивные технологические процессы самопроектирующейся личности, что, в свою очередь, может стать важным ресурсом для разработки технологий психологического сопровождения личности на этом пути.

По мере развития способности личности к самопроектированию, дискурсивные технологии, которые она применяет для создания «Я-текста» (как проекта себя и своей жизни) принципиально усложняются: от умений строить разрозненные высказывания («Я-высказывания»), отражающие ситуативную событийность на уровне «плагиатора», до способности артикулировать лейтмотив как основной автонарратив личности, запечатляющий концепцию ее жизнеосуществлений. Центральная линия, «тема» жизни, прорастающая через весь ее событийный ряд, кристаллизирующаяся на уровне «автора» и представляют собой динамическую конфигурацию ряда психологических и технологических подпроцессов.

Остановимся детальней на описании дискурсивных технологий, направленных на построение «Я-текста» личности на каждом из этих уровней, а также на характеристике технологий, позволяющих индивиду осуществлять переходы между ними в процессе развития его способности к самопроектированию.

Так, на уровне «плагиатора» индивид демонстрирует диффузный стиль текстовой объективации опыта, заимствует чужие смыслы, «чужую речь», избирательно воплощая их в собственные высказывания, отражающие отдельные ситуации 
своей жизни; «по-своему» выбирает и компонует ситуативные элементы, эксплицируя их в текстовые высказывания. Однако такая избирательность процессов текстообразования индивида на нижнем уровне самопроектирования не свидетельствует о самодетерминации обозначенных процессов и способности индивида их рефлексировать. Здесь, прежде всего, речь идет о заимствовании «готовых к употреблению», назначенных «смыслоформ» - ярлыков, «снятых смыслов» (скорее, «снятых содержаний»), в результате чего, происходит их опрощение, содержания стереотипизируются. Неспособность конденсировать и обобщать содержание собственных высказываний, в свою очередь, лишает их содержательной целостности, «содержательного ядра» темы высказывания, подменяя ее ярлыком (квазитемой).

C нашей точки зрения, именно умение выделять тему (предмет, суть) собственных и чужих высказываний, независимо от их протяженности, как их обобщенный содержательный концентрат и является той важной технологической составляющей перехода личности на уровень «читателя» по мере развития ее способности к самопроектированию. Для выделения общей темы высказываний, основанных на повседневных разрозненных ситуациях, индивиду необходимо научиться осуществлять отбор жизненного материала, его осмысление и «содержательное сжатие». При этом тема может быть как предопределенной текстом, так и иметь ассоциативный характер; может быть как вновь актуализованной уже знакомой ранее темой, так и принципиально новой.

Технология выделения темы высказывания (высказываний) предполагает обучение способам первичной организации, осмысления, упорядочения опыта личности, овладение стратегиями экспликации основной идеи, которая обретает четкую формулировку, свое словесное обозначение путем свертывания, компрессии высказывания.

По нашему мнению, основными механизмами этого процесса являются когнитивные операции понимания, прежде всего, структурирование и переструктурирование текстовой информации, eе сжатие, семантическое взвешивание и информационный диалог как прием (не всегда осознанный), помогающий индивиду прояснить содержание жизненных ситуаций, воссоздать их смысл, построить внутреннюю структуру высказывания. Данная 
технология реализуется через постановку вопросов, помогающих удерживать в памяти жизненный материал, фиксировать основные его содержательные узлы (Чепелєва, 2017).

Такие вопросы мы назвали «недиалогическими», поскольку они не являются формой субъект-субъектного взаимодействия, характерного для диалога, а, скорее, непосредственной реакцией на сообщение, которое воспринимается (Чепелєва, 2017). Технология информационного диалога как начальная, фаза взаимодействия личности с со своим жизненным текстом обеспечивает прежде всего значенческий уровень понимания. Ее можно охарактеризовать как «семиотическую технологию», пронизывающую все этапы самопроетирования, и на уровне «плагиатора» позволяющую индивиду означивать реальность, «набрасывая» на нее те или иные когнитивные структуры: организовывать и концептуализировать ее путем наложения готовых интерпретационных схем.

C нашей точки зрения, технология информационного диалога способствует реализации интенций «Я-высказывающегося» в процессе обучения личности как ставить эти вопросы, так и искать ответы на них. В контексте вышесказанного, Е.Б. Старовойтенко подчеркивает, что «высказывание относится к конкретному факту реальности, отражает, копирует его, но при этом, по формулировке Л. Витгенштейна, «имеет намерение быть чем-то другим». Оно является моделью реальности, в которой заключены возможность чего-то нового, ожидание реализации этой возможности и проект изменения объекта высказывания в соответствии с ожиданием» (Старовойтенко, 2013: 135).

Таким образом, «Я-высказывающийся» является потенциальным субъектом диалогичности, способность к которой формируется на следующих уровнях самопроектирующейся личности.

Уровень «читателя» предполагает овладение индивидом коммуникативно-семиотическими технологиями самопроектирования, в частности, технологией нарративизации жизненного опыта.

Внутри психолого-герменевтического подхода мы рассматриваем нарративизацию как технологию, позволяющую трансформировать внешние события во внутренний опыт личности путем их упорядочивания согласно признакам нарративного текста. При этом «нарративные структуры выступают в роли 
интерпретационных рамок, которые человек накладывает на осмысляемую действительность» (Проблемы психологической герменевтики, 2009: 47).

Технологию нарративизации можно охарактеризовать как процесс построения идеальных планов деятельности и коммуникации, конструирования знаково-символических систем, опосредующих взаимодействие человека с социальной реальностью в ходе интеграции различных контекстов его опыта.

Семиотические технологии здесь преобразуются в технологии создания личностью собственных интерпретационных схем посредством преобразования и трансформации личного опыта. Мы предполагаем, что семиотический механизм обеспечивает структурное, или логическое понимание означиваемой реальности на уровне денотатов («что происходит?») (Проблемы психологической герменевтики, 2009).

И если для перехода с уровня «плагиатора» на следующий, более высокий, уровень индивиду необходимо овладеть технологиями информационного диалога для выделения главной темы высказываний, носящих ситуативный характер, то на уровне «читателя» индивиду нужно освоить технологии установления причинно-следственных и пространственно-временных отношений (взаимосвязей) между событиями собственной жизни и способы их детерминации.

Нарративизация как коммуникативная технология создается всегда в диалоге с Другим, в том числе, внутренним Другим. В контексте вышесказанного, Е.Б. Старовойтенко определяет особенности такого диалога как динамики пространств «между Я и Другим», «Я-в-Другом», «Другой-в-Я» (Старовойтенко, 2013).

Технологией перехода самопроектирующейся личности с уровня «читателя» на уровень «автора» является создание произведения, представляющего собой не одну-единственную историю, а совокупность всех жизненных сюжетов, в которых оказывается Я.

И если нарратив мы рассматриваем как когнитивную схему конструирования смысла через тематическое расположение фактов в виде организованных сюжетов в пространственновременных координатах, произведение представляет собой инструмент конструирования личностной идентичности. Его можно 
рассматривать «как роман с множеством действующих лиц, в качестве которых выступают различные Я-образы человека. Однако все эти действующие лица относятся физически к одному актору, воплощенному в одном теле» (Труфанова, 2010: 189).

«Я представляется «многоголосым», ведущим непрерывный диалог с самим собой. Я индивида как «открытое произведение» - в котором сам индивид является и автором, и исполнителем, а Другие, также выступая с позиций «читателя» («слушателя») привносят свое понимание самости, дополняя создаваемый человеком Я-нарратив» (Труфанова, 2010).

«Человек рассказывает свою жизненную историю, но он не может ограничиваться только своим пониманием Я и неизбежно дополняет и видоизменяет свой Я-нарратив с помощью реакций Других на его рассказ. Таким образом, Я-нарратив, несмотря на наличие некого постоянства, обеспечиваемого его автором, находится в состоянии вечной «текучести»: он вечно уточняется, дополняется, корректируется, видоизменяется, и с помощью Других человек сам открывает все новые грани самого себя и вписывает их в свой нарратив» (Труфанова, 2010: 191).

Дискурсивные технологи самопроектирования на уровне «автора» направлены на создание произведения, которое определяется в первую очередь лейтмотивом как главной жизненной «темой» личности, избравшей в своих автонарративах определенную ценностно-смысловую «логику» их синтеза в единое смысловое целое. «Интеграция целостного жизненного опыта через призму поиска ответов на вопросы «Кто Я как человек, проживающий именно эту жизнь?», «Кто Я в своей жизни в целом?» позволяет в качестве образа идентичности сконструировать образ героя жизненного пути как субъекта жизненных решений» (Зайцева, 2016: 122).

Тут очень важным представляется умение организовать историю вокруг главной «темы» будущей жизни и себя в ней. Тема или тематическая структура является главной единицей автонарратива, в которой отражается основная тенденция повествования. Она присутствует в тексте любого жанра, ее особенность в повествовательном тексте состоит в том, что именно автонарратив, как личностная структура, побуждает ту или иную интерпретацию событий, воплощаемую в тексте-повествовании. 
В процессе создания целостной истории собственной жизни такие смысловые линии, темы переплетаются, взаимодействуют, а иногда и конкурируют между собой, создавая общую смысловую тему, составляющую жизненную канву, линию жизни личности.

Такой смысловой линией, в большой степени определяющей личность, является лейтмотив. Он пронизывает все смысловое пространство личности как ведущая линия личностного развития, ведущая жизненная «тема». Именно лейтмотив объединяет автонарративы, часто разорванные и разрозненные, в одну жизненную историю, в одно произведение. Его можно рассматривать как общую концепцию жизни, которая хотя и меняется со временем, но постоянно возвращает личность к ключевой для него «мелодии», жизненной теме. Лейтмотив является основой для создания жизненного сюжета, который связывает основные темы, отражающие события жизни, в упорядоченную последовательность.

Таким образом, лейтмотив как «доминирующая тема» жизненного произведения личности становится его каркасной конструкцией, удерживающей (как в синхронии, так и в диахронии) его разнородные фактологические и рефлексивные составляющие в пределах динамического единства и позволяющей личности вступать с Другим в отношения со-авторства.

Лейтмотив является той осью, вокруг которой разворачивается бесконечный цикл интерпретаций и осмыслений, системообразующим принципом произведения личности как результата кодификации его жизненного материала, а значит, он обладает возможностью управления его пониманием путем декодирования смысловых моделей, вокруг которых произведение «наращивалось». Таким образом, лейтмотив представляет собой не только опору жизненного произведения как целого, но и средство навигации личности в его пределах.

Лейтмотив содержит концепты - ментальные и эмоционально окрашенные «сращения понятия и образа», вербализированные минимальные единицы человеческого опыта. Как подчеркивалось нами ранее, основным способом организации опыта личности на уровне «автора» являются тезаурусы (Чепелєва \& Рудницька, 2018), интерпретируемые В.А. Луковым и Вл.А. Луковым как «полный систематизированный свод освоенных социальным субъектом знаний, существенных для него как средство ориентации 
в окружающей среде, а сверх этого также знаний, которые непосредственно не связаны с ориентационной функцией, но расширяют понимание субъектом себя и мира, дают импульсы для радостной, интересной, многообразной жизни» (Луков \& Луков, 2014: 18). Таким образом, тезаурус может быть охарактеризован как ориентационный (сверхориентационный) комплекс и осмыслен как источник и результат социокультурной субъектности.

Строительным материалом тезауруса, прежде всего, выступают концепты как идеальные объекты, моделирующие определенные ценностно-смысловые представления человека о самом себе и об окружающем его мире. В силу того, что концепты личности складываются из слоев, различных по времени происхождения, можно представить их «эволюцию» в виде фракталов, звеньями которых являются «стадии развития» концепта, в определенном смысле, подобные целому (даже в небольшой части фрактала содержится информация обо всем фрактале).

Концепты, составляющие содержание лейтмотива, представляют собой эмержентные образования, постоянно преобразующиеся в процессе конструирования опыта. Можно заключить, что лейтмотив жизненного произведения (как и само жизненное произведение личности в целом) имеет «смысловые свойства», превосходящие свойства суммы компонентов концептуальной системы личности, что, в свою очередь, и дает возможность личности создавать собственные смысловые системы, являющиеся основой для создания жизненных и личностных проектов. «Главное не в самих отдельно взятых смыслах, а в том, что их связывает в единую сеть, в единую систему. Не существует отдельных, изолированных смыслов, есть единая смысловая система. Что-то имеет для человека смысл благодаря тому, что оно включено в эту систему» (Леонтьев, 2014: 108).

В процессе создания технологии построения авторского текста (произведения), отражающего личностный проект человека нужно, по нашему мнению, учитывать следующие требования к такому тексту:

1. Наличие главной темы (лейтмотива), под которой подразумевается некоторый общий знаменатель или общая тенденция ряда рассказов. Причем в рассказе таких тем может быть несколько, и они иногда переплетаются между собой. 
2. Наличие главного героя рассказа, подразумевая, что рассказ человека - это, в сущности, рассказ о нем самом. При этом, несмотря на большое количество действующих лиц, которые могут присутствовать в рассказе, все же возможно говорить о преимущественной идентификацией с кем-либо из персонажей. В рассказе есть проекции различных граней самого себя и способ их представления. При этом может быть идентификация, как с героями, так и с позицией автора (даже если рассказ ведется от первого лица, эти идентификации могут расходиться).

3. Отражение в тексте главных потребностей и мотивов героя (или героев).

4. Присутствие в тексте рассказа персонажей, предметов и обстоятельств, а также, напротив, игнорируемые автором.

5. Описание среды и представление об окружающем мире, которая в зависимости от атмосферы рассказа может быть охарактеризована двумя-тремя прилагательными, например, опекающая, враждебная, агрессивная и пр.

6. Отражение основных конфликтов и сопутствующих им защит, а также природы основных страхов.

Таким образом, в результате ценностно-смысловой интеграции жизненной истории личности на уровне «автора», трансформационного синтеза корпуса ее автонарративов постепенно оформляется жизненное произведение, запечатляющее ее личностные проекты.

\section{Выводы}

Дискурсивные технологии на каждом из выделенных нами трех уровнях самопроектирующейся личности («плагиатора», «читателя», «автора») имеют свою выраженную специфику, обусловленную способами организации опыта личности, текстовой объективации этого опыта, стратегиями смыслообразования, способами и процедурами понимания.

Основной дискурсивной технологией личности на уровне «плагиатора» является высказывание. Технологией перехода на уровень «читателя» служит информационный диалог, в процессе которого эксплицируется тема высказываний, что, в свою очередь, 
запускает процесс структурирования, фреймирования «жизненного материала» личности, порождения нарративных конструктов. Нарративизация становится основной дискурсивной технологией личности на уровне «читателя». Для перехода на факультативный уровень «автора» личности необходимо освоить технологию смыслового диалога, в процессе которого происходит создание автонарративов. На уровне «автора», благодаря определенной ценностно-смысловой «логике» интеграции автонарративов в единое смысловое целое, рождается жизненное произведение личности, опорой которого, а также средством навигации личности в его пределах выступает лейтмотив.

Таким образом, можно обобщить, что дискурсивные технологии самопроектирования личности направлены на:

- тематическую организацию жизненных ситуаций на уровне «плагиатора»;

- пространственно-временную и причинно-следственную структурализацию жизненных событий на уровне «читателя»;

- ценностно-смысловую интеграцию жизненной истории на уровне «автора».

Вышеобозначенные позиции характеризуют принципиальные содержательные отличия «авторского» уровня самопроектирования личности, на котором в процессе движения лейтмотива в пространстве жизненного произведения эксплицируется его «индивидуальный облик», прорастает лик (А.Ф. Лосев) личности, взращивается Личностность.

Перспективы дальнейших исследований мы связываем с разработкой тренинговой развивающей среды, способствующей становлению позиции авторства в процессе самопроектирования личности.

\section{Литература}

Воробьева Л.И. Субъект и/или автор (о категориях гуманитарной психологии). Вопросы психологии. 2004. № 2. С. 149-158.

Зайцева Ю.Е. Я-нарратив как инструмент конструирования идентичности: экзистенциально-нарративный подход. Вестник СПбГУ. Сер. 16.2016. Вып. 1. С. 118-136.

Казаков И.С. Самопроектирование - анализ понятия. Вестник СГУТиКД. 2011. № 2(16). C. 130-133. 
Леонтьев Д.А. Личностное измерение человеческого развития. Bonpocbl психологии. 2013. № 3. С. 67-80. doi. 10.1016/S0304-3959(03)00003-4

Леонтьев Д.А. Смыслообразование и его контексты: жизнь, структура, культура, опыт. Мир психологии. 2014. № 1. С. 104-117.

Луков В.А., Луков В.А. Методология тезаурусного похода: стратегия понимания. Знание. Понимание. Умение. 2014. № 1. С. 18-35.

Мамардашвили М.К. Эстетика мышления. Москва: Моск. Школа полит. исследов., 2001. $416 \mathrm{c}$.

Проблемы психологической герменевтики / Под ред. Н.В. Чепелевой. Киев: Изд-во Национального педагогического ун-та им. Н.П. Драгоманова, 2009. 382 c.

Самопроектування особистості у дискурсивному просторі: монографія / Н.В. Чепелєва, М.Л. Смульсон, О.В. Зазимко, С.Ю. Гуцол та ін.; за ред. Н.В. Чепелєвої. Київ: Педагогічна думка, 2016. 232 с.

Старовойтенко Е.Б. Возможности «Я» в отношении к другому: герменевтика и рефлексия. Психология. Журнал Высшей школьл экономики. 2013. Т. 10. № 4. C. $121-142$.

Труфанова Е.О. Я-нарратив и его автор. Философия науки. 2010. Вып. 15. C. $183-193$.

Тюнников Ю.С. Социокультурное и педагогическое проектирование: проблемы взаимодействия. Известия высших учебных заведений. Северо-Кавказский регион. Общественные науки. 2000. № 1. С. 100-104.

Чепелєва Н.В., Рудницька С.Ю. Психологічна характеристика особистості, здатної до самопроектування. Педагогіка і психологія. 2018. № 1. С. 71-77.

Чепелєва Н.В. Розуміння - Інтерпретація - Тлумачення. Технології розвитку інтелекту. 2017. Т. 2. Вип. 6(17). URL : http://psytir.org.ua/index.php/ technology intellect develop/article/view/301 (дата звернення : 12.02.2019).

Baddeley, J., \& Singer, J.A. (2007). Charting the life story's path: Narrative identity across the life span. In J. Clandinin (Ed.), Handbook of narrative research methods (pp. 177-202). Thousand Oaks, CA: Sage. https://doi. org/10.4135/9781452226552.n7

Bauer, J.J., \& McAdams, D.P. (2004). Personal growth in adults' stories of life transitions. Journal of Personality, 72, 573-602. https://doi.org/10.1111/j.00223506.2004.00273.x

Eco, U. (1984). Semiotics and the philosophy of language. Indiana University Press. https://doi.org/10.1007/978-1-349-17338-9

Gergen, K. (1999). An invitation to social construction. London: Sage.

Habermas, T., \& de Silveira, C. (2008). The development of global coherence in life narratives across adolescence: Temporal, causal, and thematic aspects. Developmental Psychology, 44, 707-721. https://doi.org/10.1037/0012-1649.44.3.707

Hammack, P.L. (2008). Narrative and the cultural psychology of identity. Personality and Social Psychology Review, 12, 222-247. https://doi. org/10.1177/1088868308316892

McAdams, D.P. (2008). Personal narratives and the life story. In O. John, R. Robins \& L. Pervin (Eds.), Handbook of personality: Theory and research (3rd ed.), (pp. 242-262). New York: Guilford Press.

McLean, K.C., Pasupathi, M., \& Pals, J.L. (2007). Selves creating stories creating selves: A process model of self-development. Personality and Social Psychology Review, 11, 262-278. https://doi.org/10.1177/1088868307301034 
Pals, J.L. (2006). Authoring a second chance in life: Emotion and transformational processing within narrative identity. Research in Human Development, 3, 101120. https://doi.org/10.1207/s15427617rhd0302\&3 3

Sarbin, T.R. (1986). The narrative as a root metaphor for psychology. In T.R. Sarbin (Ed.), Narrative psychology: The storied nature of human conduct (pp. 3-21). New York: Praeger.

Wittgenstein, L. (2009). Philosophical investigations (4th edition). Oxford. UK: WileyBlackwell.

\section{References}

Vorobyeva, L.I. (2004). Subyekt i/ili avtor (o kategoriyakh gumanitarnoy psikhologii) [Subject and / or author (on categories of humanitarian psychology)]. Voprosy psikhologii - Psychology, 2, 149-158 [in Russian].

Zaytseva, Yu.Ye. (2016). Ya-narrativ kak instrument konstruirovaniya identichnosti: ekzistentsialno-narrativnyy podkhod [Self-Narrative as a Tool for Identity Design: An Existential-Narrative Approach]. Vestnik SPbGU - Saint-Petersburg University bulletin, 16(1), 118-136 [in Russian].

Kazakov, I.S. (2011). Samoproyektirovaniye - analiz ponyatiya [Self-designing analysis of the concept]. Vestnik SGUTiKD - Journal «Sochi Journal of Economy», 2(16), 130-133 [in Russian].

Leontyev, D.A. (2013). Lichnostnoye izmereniye chelovecheskogo razvitiya [The personal dimension of human development]. Voprosy psikhologii - Psychology, 3, 67-80 [in Russian].

Leontyev, D.A. (2014). Smysloobrazovaniye i yego konteksty: zhizn, struktura, kultura, opyt [Sense formation and its contexts: life, structure, culture, experience]. Mir psikhologii - The world of psychology, 1, 104-117 [in Russian].

Lukov, V.A., \& Lukov, V.A. (2014). Metodologiya tezaurusnogo pokhoda: strategiya ponimaniya [Methodology of the thesaurus: the understanding strategy]. Znaniye. Ponimaniye. Umeniye - Knowledge. Understanding, 1, 18-35 [in Russian].

Mamardashvili, M.K. (2001). Estetika myshleniya [Aesthetics of thinking]. Moscow: Mosk. Shkola polit. issledov. [in Russian].

Chepeleva, N.V. (Ed.). (2009). Problemy psikhologicheskoy germenevtiki [Problems of psychological hermeneutics]. Kyiv: Izd-vo Natsionalnogo pedagogicheskogo un-ta im. N.P. Dragomanova [in Ukrainian].

Chepeleva, N.V., Smulson, M.L., Zazimko, O.V., \& Gutsol, S.Yu. (2016). Samoproektuvannja osobistosti u diskursivnomu prostori [Self-design of a person in a discursive space]. Kyiv: Pedahohichna dumka [in Ukrainian].

Starovoytenko, Ye.B. (2013). Vozmozhnosti ya v otnoshenii k drugomu: germenevtika i refleksiya [Possibilities for me in relation to another: hermeneutics and reflection]. Psikhologiya. Zhurnal Vysshey shkoly ekonomiki - Psychology. Journal of Higher School of Economics, 10(4), 121-142 [in Russian].

Trufanova, Ye.O. (2010). Ya-narrativ i yego avtor [Self-narrative and its author]. Filosofiya nauki - Philosophy of science, 15, 183-193 [in Russian].

Tyunnikov, Yu.S. (2000). Sotsiokulturnoye i pedagogicheskoye proyektirovaniye: problemy vzaimodeystviya [Sociocultural and pedagogical design: problems of interaction]. Izvestiya vysshikh uchebnykh zavedeniy. Severo-Kavkazskiy region. 
Obshchestvennyye nauki - Proceedings of higher educational institutions. North Caucasus region. Social Sciences, 1, 100-104 [in Russian].

Chepeleva, N.V., \& Rudnicka, S.Yu. (2018). Psiholohichna harakterystyka osobystosti, zdatnoi do samoproektuvannja [Psychological characteristic of a person capable of self-design]. Pedahohika i psiholohija - Pedagogy and psychology, 1, 71-77 [in Ukrainian].

Chepeleva, N.V. (2017). Rozuminnia - Interpretatsiia - Tlumachennia [Understanding Interpretation - Explication]. Tekhnolohii rozvytku intelektu - Technologies of Intellect Development, Vol 2, 6(17) [in Ukrainian].

Baddeley, J., \& Singer, J.A. (2007). Charting the life story's path: Narrative identity across the life span. In J. Clandinin (Ed.), Handbook of narrative research methods (pp. 177-202). Thousand Oaks, CA: Sage. https://doi. org/10.4135/9781452226552.n7

Bauer, J.J., \& McAdams, D.P. (2004). Personal growth in adults' stories of life transitions. Journal of Personality, 72, 573-602. https://doi.org/10.1111/j.00223506.2004.00273.x

Eco, U. (1984). Semiotics and the philosophy of language. Indiana University Press. https://doi.org/10.1007/978-1-349-17338-9

Gergen, K. (1999). An invitation to social construction. London: Sage.

Habermas, T., \& de Silveira, C. (2008). The development of global coherence in life narratives across adolescence: Temporal, causal, and thematic aspects. Developmental Psychology, 44, 707-721. https://doi.org/10.1037/00121649.44.3.707

Hammack, P.L. (2008). Narrative and the cultural psychology of identity. Personality and Social Psychology Review, 12, 222-247. https://doi. org/10.1177/1088868308316892

McAdams, D.P. (2008). Personal narratives and the life story. In O. John, R. Robins \& L. Pervin (Eds.), Handbook of personality: Theory and research (3rd ed.), (pp. 242-262). New York: Guilford Press.

McLean, K.C., Pasupathi, M., \& Pals, J.L. (2007). Selves creating stories creating selves: A process model of self-development. Personality and Social Psychology Review, 11, 262-278. https://doi.org/10.1177/1088868307301034

Pals, J.L. (2006). Authoring a second chance in life: Emotion and transformational processing within narrative identity. Research in Human Development, 3, 101120. https://doi.org/10.1207/s15427617rhd0302\&3_3

Sarbin, T.R. (1986). The narrative as a root metaphor for psychology. In T.R. Sarbin (Ed.), Narrative psychology: The storied nature of human conduct (pp. 3-21). New York: Praeger.

Wittgenstein, L. (2009). Philosophical investigations (4th edition). Oxford. UK: WileyBlackwell.

\section{АННОТАЦИЯ}

В статье представлена и проанализирована трехуровневая модель самопроектирующейся личности («плагиатор», «читатель», «автор») и охарактеризованы психологические особенности субъекта самопроектирования на каждом из них. В оптике психолого-герменевтичного подхода предложена 
концепция понимания дискурсивной технологии как коммуникативносемиотического прочесса, который обеспечивает хранение, аккумуляцию, трансформацию, трансляцию и ретрансляцию ценностно-смыслового ресурса, инкорпорированного в определенные знаково-символические формы, в частности, в широкого спектра социокультурные и личностные тексты. Показано, что дискурсивные технологии на каждом из выделенных уровней самопроектирования имеют выраженную специфику, обусловленную способами организации опыта личности, текстовой объективации этого опыта, стратегиями смыслообразования, способами и прочедурами понимания. Основной дискурсивной технологией на уровне "плагиатора» является высказывание. Технологией перехода на уровень «читателя» служит информационный диалог, в процессе которого эксплицируется тема высказываний, которые, в свою очередь, запускают процесс структурирования, фреймирования "жизненного материала» личности, порождения нарративных конструктов. Нарративизация становится основной дискурсивной технологией личности на уровне «читателя». Для перехода на фракультативный уровень "автора» личность должна овладеть технологией смыслового диалога, в прочессе которого происходит создание автонарративов. На уровне «автора», благодаря определенной ценностно-смысловой "логике» интеграции автонарративов в единое смысловое целое, рождается жизненное произведение личности, остовом которого, а также средством навигации личности в пределах которого выступает лейтмотив. Обобщенно, что дискурсивные технологии самопроектирования личности направлены на: тематическую организацию жизненных ситуаций на уровне "плагиатора»; пространственно-временную и причинно-следственную структурализацию жизненных событий на уровне "читателя»; ценностно-смысловую интеграцию жизненной истории на уровне "автора».

Ключевые слова: текст, самопроектирование, нарратив, дискурсивные технологии самопроектирования, информационный диалог, смысловой диалог.

\section{Чепелєва Наталія, Рудницька Світлана. Дискурсивні технології особистості, що самопроектується}

\section{АНОТАЦІЯ}

У статті представлено та проаналізовано трирівневу модель особистості, що самопроектується: "плагіатор», "читач», "автор», та схарактеризовано психологічні особливості суб'єкта самопроектування на кожному з них. В оптиці психолого-герменевтичного підходу запропоновано концепцію розуміння дискурсивної технології як комунікативно-семіотичного процесу, що забезпечує зберігання, акумуляцію, трансрормацію, трансляцію та ретрансляцію ціннісносмислового ресурсу, інкорпорованого в певні знаково-символічні фооми, зокрема, в широкого спектра соціокультурні й особистісні тексти. Показано, що дискурсивні технології на кожному з виділених рівнів самопроектування мають 
виражену специфіку, зумовлену способами організації досвіду особистості, текстової об'єктивації цього досвіду, стратегіями смислотворення, способами і процедурами розуміння. Основну дискурсивну технологією на рівні "плагіатора» становить висловлювання. Технологією переходу на рівень «читача» служить інформаційний діалог, у прочесі якого есплікується тема висловлювань, що, у свою чергу, запускає процес структурування, фреймування «життєвого матеріалу» особистості, породження наративных конструктів. Наративізація стає основною дискурсивною технологією особистості на рівні «читача». Для переходу на факультативний рівень "автора» особистість має опанувати технологію смислового діалогу, у процесі якого відбувається створення автонаративів. На рівні «автора», завдяки певній ціннісно-смисловій "логіці» інтеграції автонаративів у єдине смислове ціле, народжується життєвий твір особистості, остовом якого, а також засобом навігації особистості в межах якого виступає лейтмотив. Узагальнено, що дискурсивні технології самопроектування особистості спрямовані на: тематичну організацію життєвих ситуацій на рівні "плагіатора»; просторово-часову та причинно-наслідкову структуралізацію життєвих подій на рівні «читача»; ціннісно-смислову інтеграцію життєвої історії на рівні «автора».

Ключові слова: текст, самопроектування, наратив, дискурсивні технології самопроектування, інформаційний діалог, смисловий діалог. 